\title{
Coldspots and Hotspots of Agriculture in Nigeria; Any Hope for Youth and Women?
}

\author{
Abioye Oyewale ${ }^{1,3^{*}}$ and Ogunniyi Adebayo ${ }^{2}$ \\ ${ }^{1}$ Centre for Entrepreneurship and Innovation, University of Ibadan \\ ${ }^{2}$ Department of Agricultural Economics, University of Ibadan, Nigeria \\ ${ }^{3}$ International Institute of Tropical Agriculture, Ibadan, Nigeria
}

\begin{abstract}
Africa has 25 percent of the world's arable land, yet it cannot boast of food sufficiency let alone tapping into food export opportunities. It is no longer news that the women folks in Africa are greatly marginalised and confronted by numerous challenges. Meanwhile, youth engagement in agriculture is presently seen as one of the ways to achieve zero hunger by 2030 as set by the sustainable development goals. Using critical review approach, this study aims to review past and present agriculture programs aimed at encouraging youth and women in agriculture. We found that access to land and weak land tenure system; high cost and unavailability of inputs, infrastructural deficit; poor access to information; inadequate extension service and poor pricing policy are the main constraints for the youth and women in Nigeria. However, opportunities such as employment, large market, vast arable land, increasing investment of government and private sector and value addition. The policy message from this study is straight: effort should be intensified and constructive approaches through polices that support pathways in which opportunities can be harnessed and constraints offed.
\end{abstract}

Keywords: Youth, Women, Nigeria, Opportunities, Constraints

\section{Introduction}

According to UN DESA, 2015, the current world population of 7.3 billion is expected to reach 8.5 billion by 2030, 9.7 billion in 2050 and 11.2 billion in 2100 . Nearly 90 per cent of the increase is expected to be concentrated in Asia and Africa (UN DESA, 2015). Agricultural development in Nigeria and Africa at large has been greeted with the development of many policies but this has not been followed up with actions. 85 percent of youth (defined by the ILO as all those between the ages of 15 and 24 years) in Sub Sahara Africa are poor, 70 percent live in rural areas where agriculture is the main source of their income and subsistence, and 11 million youth are expected to enter the labor market every year for the next decade (World Bank 2015 sited in Adesugba and Mavrotas, 2016). The Nigeria National Population Commission (NPoC, 2013) defined a youth as male or female between ages 18 and 35 years. In this study, women are referred to as female from age 36 upward. To have holistic economic growth, it is important that youth engagement in 
agriculture should be backed with enabling policies. Currently, youth engagement in agriculture is a pressing issue receiving attention from the African Development Bank, African Union and some other regional institutions.

Youth and women in agriculture are an important aspect of the African Development Bank's current agriculture initiative. The Feed Africa Strategy is geared towards reversing the US $\$ 35.4$ billion spends on food imports annually by African countries in spite of being home to $65 \%$ of the world's undeveloped arable land (AFDB, 2016). Nigeria's Green alternative and Zero Hunger initiatives are also setup to feed into the AFDB strategy. With Nigeria been the most populous nation in Africa, the AFDB's ambition cannot be met if the business of producing food is left in the hand of the ageing farmers. As at 2016, Nigeria population was $186,053,386$ with average farmers' age being 55 years and above constituting $7 \%$ of the population, youth and women constitute over $50 \%$ while citizens between age $0-14$ takes the remaining $43 \%$ as shown in Figure 1 (CIA World fact book 2016). With this, it is apparent that if the youth and women are not attracted to this sector, the cost of importing food will continue to increase at an alarming rate. This overwhelming population has caused supply to out strip demand especially in the formal employment sector (Bakare 2011). Unemployment is undoubtedly the most challenging socio - economic problem confronting the country (Olokundun et al, 2014). Unemployment as described by Kakwagh and Ikwuba (2010) has affected the youths and women in Nigeria from a broad spectrum of socio - economic groups.

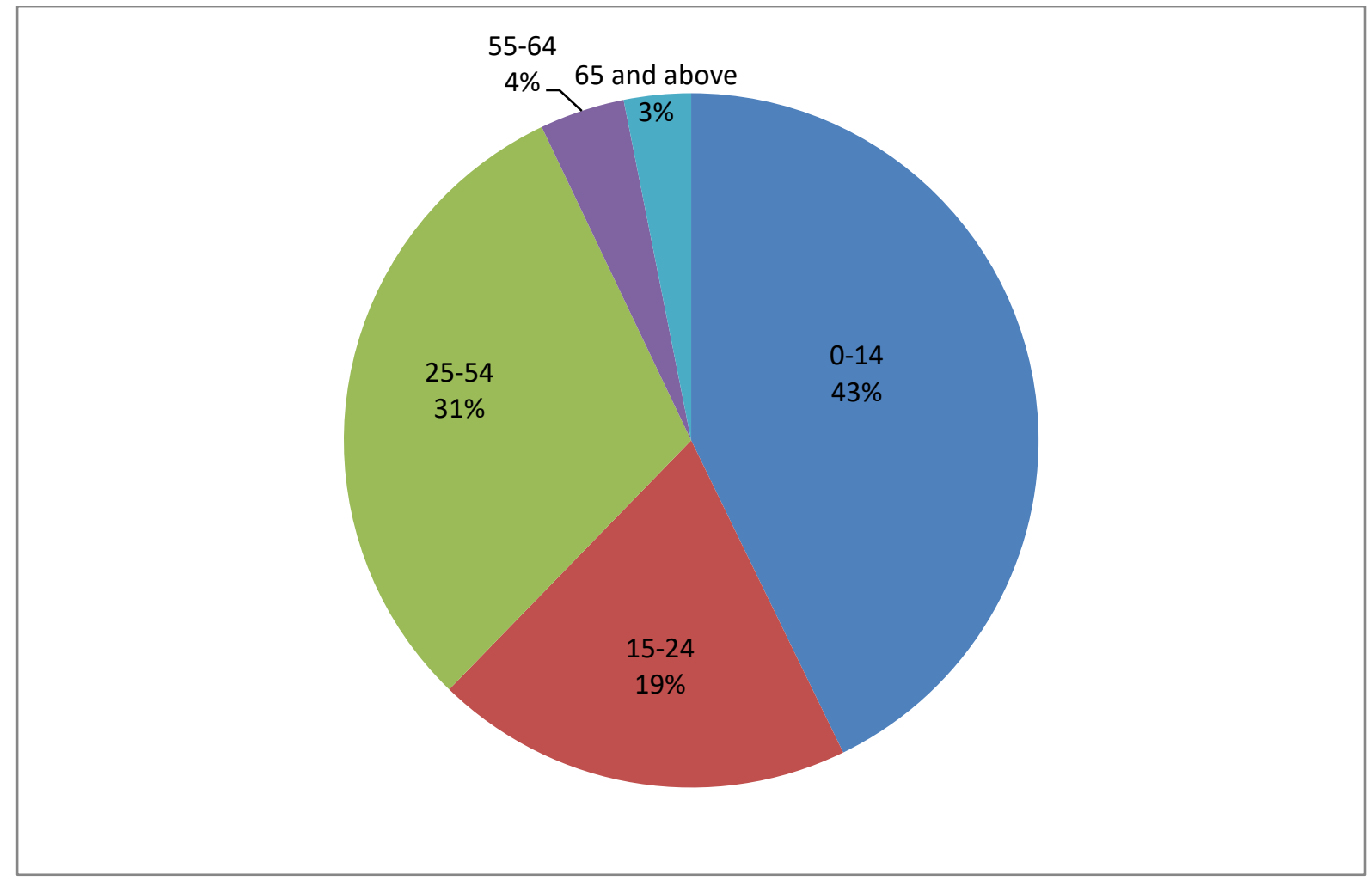

Figure 1: Nigeria population in percentage distribution by age; Source: CIA World Factbook (2016)

Youths and women are an integral part of the society and their contributions cannot be undermined. According to Skuza (2005), youths are a vital segment of human which can shoulder future development in agriculture and rural sectors. A major setback that the governments have faced is the non-integration of youth in the agricultural and rural development planning (Adeogun, 2015). Policies in many Sub-Sahara African countries pointed to agriculture as the channel for industrialization and emphaises the need for youth to play critical role in driving the transformation of agriculture in the continent. However, Agriculture suffers from entrenched negative perceptions among African youths. Therefore, the success of this strategy 
Oyewale et al. Adv. J Social Sci.; Vol. 2 Issue 1, pp: 1-11, May 2018

depends largely on how well government and development agents can project the value in the agricultural value chains to the youth. The dearth to this is that, on one hand, most youths are lured by opportunities in other sectors like services and oil and gas in urban areas which attract them away from rural areas. On the other hand, youths are constrained by limited access to land, high costs of inputs, erratic rainfall, loss of soil fertility, and lack of agricultural services and credit (Dyer, 2013). This is somewhat similar to the challenges that women face in agriculture.

It is no longer news that the women folks in Africa are greatly marginalised and confronted by challenges such as limited access to productive resources, markets, training, credit facilities and cooperative memberships. Women, nevertheless, continue to be a major player in the development of the rural economy and play several social and economic roles in agricultural societies (FLA, 2015). Laven and Verhart (2012) argued that current interventions have been directed towards the women participation in agriculture yet more work still need to be done. Against this backdrop, this study aims to review past and present agriculture programs aimed at encouraging youth and women in agriculture. We also identify and diagnose opportunities and constraints to youths and women in agriculture and suggest policies pathways through which opportunities can be harnessed and constraints offed.

\section{Nigeria Government Investment in Agriculture with Focus on Youth and Women (1987 - 2015)}

Over the years, several government programmes have been initiated to stimulate youth interest and foster women's participation in agricultural production and processing. Some of the programmes include:

\subsection{National Directorate of Employment (NDE)}

Effort to reduce the rate of unemployment in Nigeria particularly among youth led to the establishment of the National Directorate of Employment (NDE) in 1987, NDE was created to provide vocational training to the youth. Out of the four focus areas (Vocational skills Development (VSD), Small Scale Enterprise (SSE) Programme, Special Public Works (SPW) Programme; and Rural Employment Promotion) of the directorate, the Rural Employment Promotion (REP) was targeted at empowering youth in the rural areas in agricultural development.

\subsection{People's Bank}

The bank was setup by the government of former President Ibrahim Babangida Administration in Lagos in the year 1989 to reduce unemployment in the country by providing traders and poor entrepreneurs with easy credit and encourage economic self-reliance at the grassroot (Anyanwu and Uwatt, 1993).one of its objectives was to end rural-urban migration by supporting the development of the rural economy.

\subsection{Community Banks}

Community bank was established in 1990 to bridge the gap between the peoples bank and the mainstream bank (commercial bank) as the people's bank was restricted by stipulated credit ceiling for each client. It was put in place to support agricultural production and other micro enterprises, with special consideration for youth engaged in agricultural production (Okoye and Okpala, 2001).

\subsection{FADAMA}

In 1992, the Fadama programme was initiated to enhance food self-sufficiency, reduce poverty, and create opportunities for employment for youths in the rural areas (Akpan, 2010).

\subsection{Youth Enterprise with Innovation in Nigeria (YOUWIN)}

YOUWIN was launched in 2011 by the former President Goodluck Jonathan's administration. The program was established to provide grant for graduates of tertiary institutions in Nigeria between ages 1840 to start a business that can generate employment for unemployed youth in the country (Akande, 2014). The first edition which was tagged YouWin1 was initiated for male and female graduates. In the first stage, 
$22.75 \%$ of the grant went to youth and women in agriculture. Foods and drinks sector which is a value chain of agriculture took $9.75 \%$. The second edition tagged YouWin 2 targeted at female graduates between 18 and 45 years of age. $24.83 \%$ of the grant in this stage went to agriculture while 12.92 were awarded to Food and drinks sector. This shows an increasing encouragement of youth and women in agriculture. The third edition YouWin!3 was Poly-gender with a record awardee of over 2500 Youth (Wikipedia, 2017).

\subsection{Youth Employment in Agriculture Program (YEAP)}

Youth Employment in Agriculture Program (YEAP) was inaugurated in December 2014. YEAP was designed in collaboration with the technical arm of the Food and Agricultural Organization of the United Nations (FAO). The programme was setup by the government with the aim of creating job opportunities for 758,500 youths between 18 and 35 years of age through their engagement in agriculture and to boost agricultural productivity. 740,000 jobs out of the 758,500 would be 'market-oriented producers' for young agricultural producers, while the remaining 18,500 jobs will be for university graduates, named 'nagropreneurs' (Adesugba and Mavrotas, 2016).

\section{Constraints for Youth and Women in Agriculture in Nigeria}

The involvement of youth in agriculture is the future of food security in Africa. Yet considering the state of agriculture around the world, few young people see a future and prospect for themselves in agriculture or rural areas. All boils down to many hurdles faced by them or perceived to be faced in their effort to earn a living. Pressure on arable land is high in many parts of the world, making it difficult to have access to land or start a farm. Youth usually lack access to credit, and many other productive resources necessary venturing and succeeding in agriculture. Particularly in developing countries like Nigeria, rural youth find themselves in such a bind. While most of the world's food is produced by (ageing) smallholder farmers in developing countries, older farmers are less likely to adopt the new technologies needed to sustainably increase agricultural productivity, and ultimately feed the growing world population while protecting the environment. Hence, we need to engage youth in agriculture. Therefore, we were motivated to assess the possible constraints youth are facing in engaging in agriculture. The following constraints were considered in the study:

\subsection{Access to Land}

Access to land is extremely crucial for insightful youth sighting agriculture as a source of livelihood. Land access is not only necessary requirement for initiating farming mechanism, but it can also enhance value chain synergy fostering contribution to household food security and is a means for reducing unemployment and livelihood diversification. Youth participating in the joint MIJARC/IFAD/FAO project reported that access to land serves as security and collateral for accessing credit, marks youth' identity, upgrades their status, and often enables participation in community producers' organizations (MIJARC/IFAD/FAO, 2012). Globally, youth perceived access to land as central for attracting them to farming, yet they face greater challenges than adults. Moreover, the challenges faced by young men in accessing land, young women face more in Sub-Saharan Africa countries like Nigeria (FAO, 2014).

Most land in Africa and specifically in Nigeria are not registered with the government; up to 80 percent of them are under communal ownership (UNCTAD 2010). This has been considered to be a major hinderance to increasing agricultural productivity as farmers are not likely to make necessary investment in the absence of secured rights (Godfray et al., 2010). Failure to resolve this issue has resulted in "dead capital"; a situation where lack of property rights makes it impossible for farmers to use their land and things planted on it to serve as collateral to get loan with the financial institutions (De Soto, 2000).

\subsection{Access to Financial Services}

Access to financial services such as savings, insurance, pension scheme, loans to mention a few is of fundamental importance to start any agricultural activity. Even with land availability to youth for farming, 
Oyewale et al. Adv. J Social Sci.; Vol. 2 Issue 1, pp: 1-11, May 2018

financial empowerment is still crucial to cover the costs of adopting improved varieties, planting, agrochemicals and harvesting, as well as investments in improved productive capacities on the farm. Painfully, most financial service providers are unwilling and very reluctant to provide their services to youth due to their lack of collateral and financial literacy, among other reasons.

\subsection{High Input Cost and Lack of Input Availability}

Even in the face of large numbers of farmers in Sub-Sahara African countries, the continent still represents small markets for agricultural inputs, mainly due to low purchasing power and other issues beyond aggregate availability, i.e. lack of fertilizer in the appropriate formulations or important complementary inputs like spray pumps for chemicals. Additionally, dispersed local markets led to low volume purchases in a tightly concentrated seasonal window, hence, all contribute to high costs per unit of input (Michener 2014). Against this backdrop, youth interest in agriculture receives knock-down effects. The high input cost and lack of input availability were ranked in $2^{\text {nd }}$ and $4^{\text {th }}$ position respectively as major perceived constraints to agriculture in Ogunniyi et al, 2016. This implies they are critically bearing the brunt of this weak productivity driven variables.

\subsection{Low Price for Produce}

Due to insect infestation and drought, most of the farm produces command low prices in the market. This has pushed many smallholders into alternative sources of livelihood. This is a limiting factor to attract youth into agriculture. For instance, armyworm pest caused a lot of damages to maize farms in 2017 and as a matter of fact little was harvested from farms that could control the impact to some extent. It therefore means that research institutions should be encouraged to consider doing researches to combat pest's infestation into farms that can reduce the price that the crop commands. Low prices and high cost of production are the reason for food insecurity and the neglect with which many youths and women in Nigeria have greeted the call into agriculture.

\subsection{Access to Information and Inadequate Extension Service}

Lack and/or inadequate information and extension services have proven to inhibit desired productivity and acquisition of developmental skills; hinders the development of entrepreneurial ventures; operating on traditionally inclined practices and many more. There is a distinct need to improve young rural women's access to needed information and technology dissemination through extension services with a view of lubricating the run to retain youth in agriculture. Access to information and effective extension services by the youth enhances skills development, better incorporation to agricultural and building capacity in entrepreneurial skills. Furthermore, in rural areas, extension services are weak. Record has it that there is 1 extension worker per 25,000 farm households compared to the FAO best practice estimate of 1 worker to 500-1000 farm households. The weak extension service leads to poor information dissemination to smallholders on improved technologies along the agricultural value chains (Synthesis Report of the Nigeria Zero Hunger Strategic Review. 2016).

\subsection{Lack of Good Road and Postharvest Handling}

Lack of motorable road from farm to markets are major constraints driving prices of farm produces up in the market. The high prices are met with the low purchasing power of the citizens in Sub-Sahara African countries thereby forcing farmers to sell at a low price due to poor post-harvest handling or unavailability of preservation mechanism due to perishability of most crops. According to the Synthesis Report of the Nigeria Zero Hunger Strategic Review, rural producers suffer from huge post-harvest losses which are in the range of $50 \%$ for vegetables and fruits, $30 \%$ for tubers and roots, and $20 \%$ for grains. The lack of postharvest facilty forces rural producers to sell most of their produce fresh from the farm instead of storage for processing. Nigeria's present storage facility is around 300,000 tonnes which is not up to the needed capacity. 


\section{Opportunities for Youth and Women in Agriculture}

This section contains some of the available opportunities for youth and women in agriculture in Nigeria.

\subsection{Employment Opportunities}

The table 1 below produced a wealth of information on 13 key agricultural commodities in Nigeria This information included current demand and supply and a calculated deficit and promising pathways to meet that target. The food deficit that must be met in Nigeria is about 84.14 million tons, with greatest gains required in chicken, rice, wheat, palm oil, cocoa and yam. Plans to increase tomato production require special attention. Nigeria recently suffered a nationwide shortage of tomato that lasted several months and drove prices up to excessive levels (FMARD 2016). This shortage is attributed to drought, disease outbreak, and spoilage along the supply chain, but ultimately it is related to insufficient intensification of production. With the projected increase in population and average age of farmers ranging from 55years upward, it will be impossible for Nigeria to meet up with the sustainable development goal 2 (Zero Hunger) except the youth and women which formed over $50 \%$ of the population are encouraged to go into agriculture. $7 \%$ of the population formed the major farmers population which reveals that the ageing and fewer part of the population is producing the food that the active population will eat.

Table 1: Gaps in Nigeria demand and supply key farming activities in Nigeria in 2016

\begin{tabular}{|c|c|c|c|c|}
\hline \multirow[b]{2}{*}{ Crop } & Demand & Supply & & \multirow[b]{2}{*}{ Observation } \\
\hline & $\begin{array}{l}\text { (tons) in } \\
\text { million }\end{array}$ & $\begin{array}{l}\text { (tons) in } \\
\text { million }\end{array}$ & Deficit & \\
\hline Rice & 6.30 & 2.30 & -4.00 & \\
\hline Wheat & 4.70 & 0.06 & -4.64 & \\
\hline Maize/Corn & 7.50 & 7.00 & -0.50 & \\
\hline Soya Beans & 0.75 & 0.60 & -0.15 & \\
\hline Chickens & 200.00 & 140.00 & -60.00 & \\
\hline Fish & 2.70 & 0.80 & -1.90 & \\
\hline Milk / Dairy & 2.00 & 0.60 & -1.40 & \\
\hline Tomato & 2.20 & 0.80 & -1.40 & \\
\hline Yams & 39.00 & 37.00 & -2.00 & \\
\hline Oil Palm & 8.00 & 4.50 & -3.50 & \\
\hline Cocoa & 3.60 & 0.25 & -3.35 & \\
\hline Cotton & 0.70 & 0.20 & -0.50 & \\
\hline Sorghum & 7.00 & 6.20 & -0.80 & \\
\hline Total & 284.45 & 200.31 & -84.14 & $\begin{array}{l}\text { Reflecting a } 30 \% \text { deficit in current } \\
\text { agricultural production }\end{array}$ \\
\hline
\end{tabular}

Source: FMARD: 2017 Agriculture Promotion Policy

According to trading economics, 2016, the rate of unemployment among youth in Nigeria increased from 21.50 percent in first quarter to 24 percent in the second quarter of the year. Agriculture offers the solution to absorb the increasing population of the unemployed or under employed youth and women in Nigeria. If the agricultural value chain can be developed, it has capacity to employ more youth and women that cannot be employed in primary production. If a 100acre farm land of cassava can employ 50 people, a cassava starch company of half a plot size can employ over 100 youth and women in different capacities. This shows that the value in agriculture for combating unemployment is in value addition. 
Oyewale et al. Adv. J Social Sci.; Vol. 2 Issue 1, pp: 1-11, May 2018

\subsection{Large Market}

Nigeria's population is growing geometrically and there is high rate of urbanization, and market-oriented smallholders must feed these growing urban centers in large part. Population of Nigeria by gender and age (CIA World Factbook, 2016) has been given in Figure 2. According to worldometer, the total population of Nigeria as at 2017 is approximately 182 million people with almost half of the population (48\%) living in urban settlements. There is an expectation that Nigeria's population will double by 2040, rendering the achievement of zero hunger target critical to the country's future. The growing urban middle class is creating diversified market demand. Nigeria's middle class is $22 \%$ of its population and the demand for food is expanding in terms of the expected quality and range of products. This change in demand offers excellent important opportunities for increasing food production by youth and women in Nigeria.

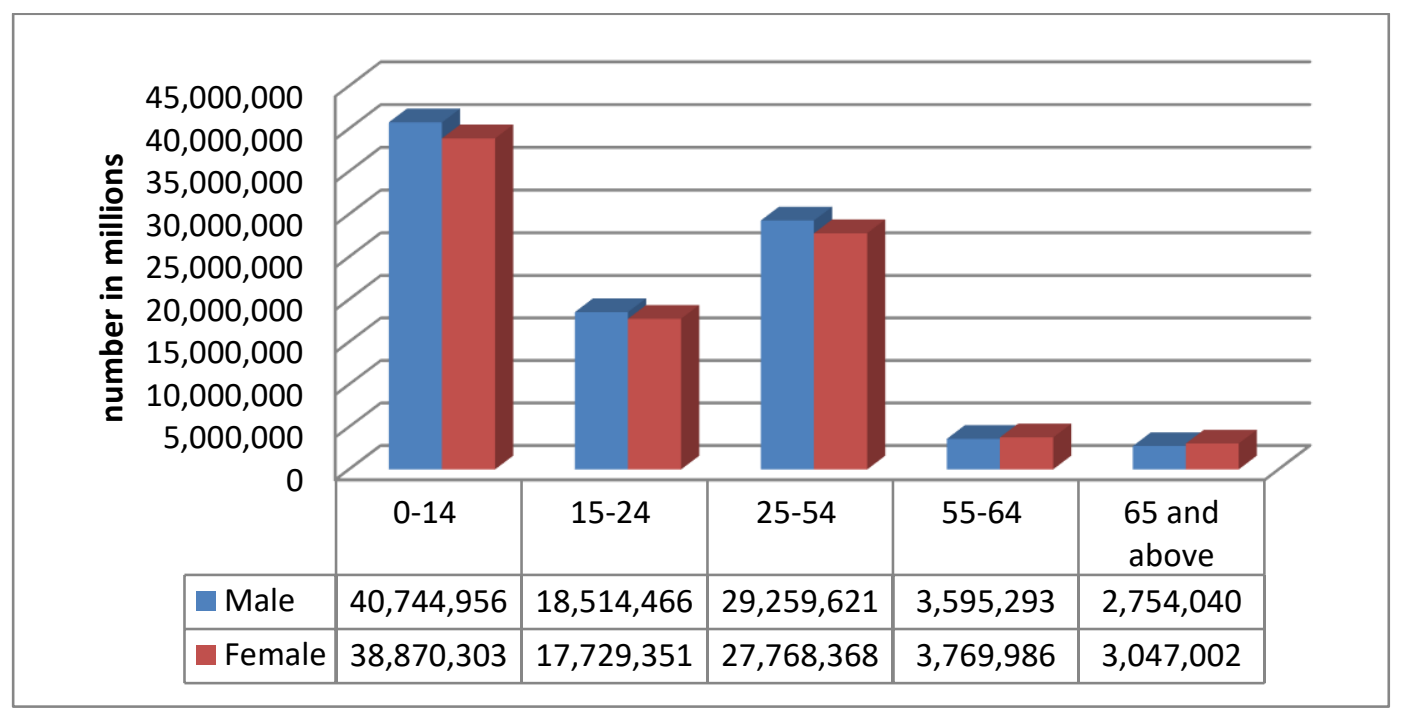

Figure 2: Nigeria population disaggregated by gender and age; Source: CIA World Factbook (2016)

\subsection{Vast Arable Land}

The value for Arable land (hectares) in Nigeria was 34,000,000 as of 2013. As the graph (Figure 3) below shows, over the past 52 years this indicator reached a maximum value of 37,000,000 in 2007 and a minimum value of 16,466,000 in 1981 (FAO 2013). Nigeria has about 79 million hectares of arable land, of which 34 million hectares are cultivated. Nigeria' agricultural activities in crop production is heavily dependent on rainfall. Majority of the farming activities are from the smallholders who cannot afford irrigation or use improved seed that are stress resistant. Both crop and livestock productions remain below potentials (Nwajiuba, 2013). There are more arable lands that have not been explored which can be used by youth and women who are receptive to climate smart agriculture to save Nigeria from impending food insecurity and provide employment to the unemployed.

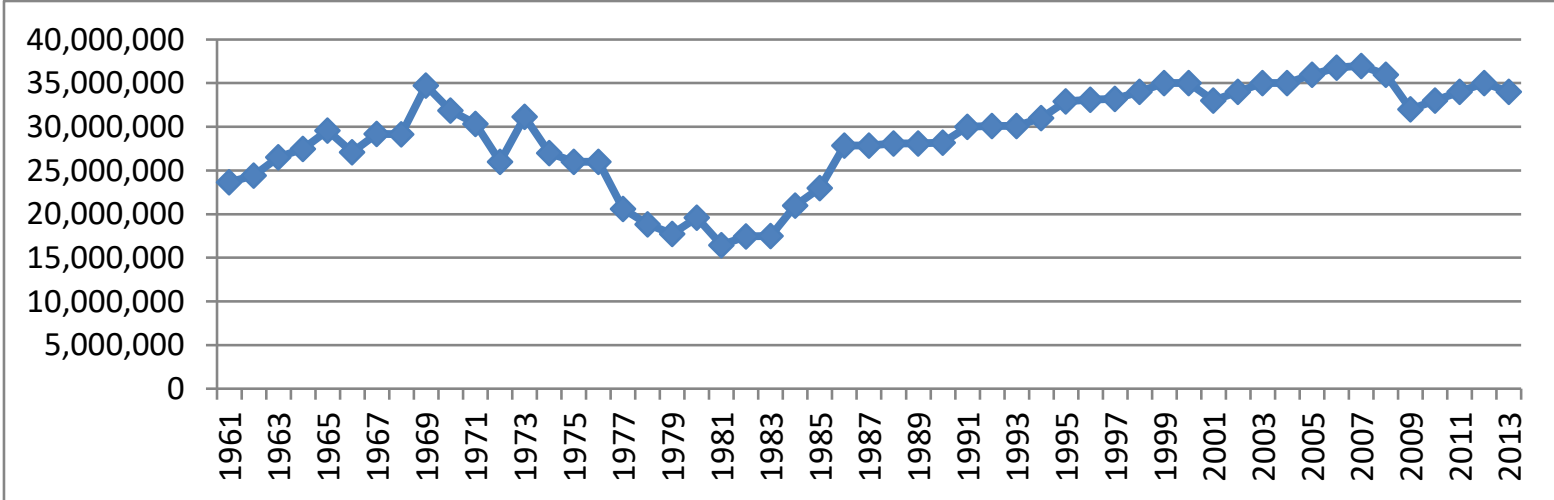

Figure 3: Nigeria's arable land from 1961 - 2013; Source: FAO 2013 


\subsection{Increasing Government and Private Sector Program Targeting Youth and Women in Agriculture}

Grants and Loan opportunities like the African Entrepreneurship Award, Tony Elumelu Foundation grant competition, Bank of Industry investment plans, Empowering Novel Agri-Business-Led Employment program to be funded by African Development bank and many more are directed towards encouraging youth and women in agriculture.

\subsection{Availability of Improved Seeds and High Yielding Livestock's}

Most smallholders in Nigeria are producing below the optimum level due to non-receptiveness to high yielding crops, drought tolerant, disease free seeds as well as good agronomic practices. Youth and women are receptive to new innovations and can tap into the available high yielding seeds or livestock to improve their production. This will in turn increase their productivity

Record has it that Nigeria is losing USD 10 billion annually due to inability to meet up with export opportunity from many countries. Demand for food internally outweighs the supply, leading to increased food imports and threatened national food self-sufficiency (FAO 2017).

\subsection{Value Addition}

A fresh watermelon from the farm costs about 250-300 Naira but same crop can be sold for 1000 Naira when processed into watermelon juice to be sold at a supermarket. This suggests that the value is in value additions. Nigeria is losing billions of dollars due to exportation of crops in their raw form instead of processing to earn foreign exchange.

It has been reported that India government improved the country's rural communities' economy by establishing agro processing industries in the villages (Njenga et al 2013). This strategy could help to create jobs in the rural areas and reduce rural-urban migration. Since nearness to raw material is a major requirement for sighting an industry, the India strategy can be embraced in Nigeria.

\section{Current Youth and Women in Agribusiness Investment Program}

\section{$5.1 \quad$ N-Power Agro}

N-Power Agro is one of the 4 N-Power programs (N-Power Agro, N-Power health, N-Power teach and N-Power tax) of the Federal government of Nigeria to employ tertiary graduates Nigeris between $18-35$ years to undertake identified public services in the areas related to their field of study. The N-Power agro's objective is to boost domestic production, achieve self-sufficiency in agriculture and ensure economic diversification. The process is for the Federal government to train and empower young graduates Nigerians in the N-power corp program as agricultural extension officer. the volunteers will be engaged in 2years agro volunteering scheme to provide knowledge and science to farmers to boost production

\subsection{Farm for Life Scheme}

The farm for life Scheme is an initiative of the Federal Ministry of Agriculture and rural development in Nigeria to create 3000 jobs in agriculture per states for youth and women in the country. The programme started with setting aside 5,000 hectares of farm land at Kerikete community and Kwali area council of Abuja. The scheme will be supported by Bank of industry and replicated in all the states of the federation.

\subsection{The Rural Finance Institution Building Programme (RUFIN)}

The Rural Finance Institution Building Programme (RUFIN) is a Loan Agreement of US $\$ 27.2$ million between the International Fund for Agricultural Development (IFAD) and the Federal Government of Nigeria. The objective is to alleviate poverty with a focus on the rural poor and especially women, youth and the physically challenged. The programme guarantees access to financial services for the disadvantaged people in the rural areas to invest and improve agricultural productivity as well as grow small businesses in the rural areas. The Federal Government of Nigeria and IFAD supported RUFIN has within one and half years of the implementation impacted on the stabilization of the Rural Microfinance sector in collaboration 
Oyewale et al. Adv. J Social Sci.; Vol. 2 Issue 1, pp: 1-11, May 2018

with the Central Bank of Nigeria (CBN). The programme has been mentoring some selected MFBs, Financial NGOs, Financial Cooperatives and the Informal/Community Credit and Savings Organisations in the twelve (12) participating states. The programme also developed a training manual for capacity building of MFBs and financial NGOs. The thirty-three (33) MFBs, ten (10) Financial NGOs selected from the outcome of Risk Institutional Assessment of NDIC/CBN and the over 4,000 Community Based Credit and Savings Organisations in the past one and half years have been subjected to vigorous capacity building and provision of necessary hardware and software ICT equipment. In line with the identified gaps from the Risk/Institutional Assessment for MFBs, Financial NGOs and Financial Cooperatives, a tailor made curriculum was designed, to ensure their capacitation. Office equipment such as desktop computers and hardware were distributed to 32 participating MFBs.

As part of the capacity building of MFls, MFBs and RMFls, which is one of the core mandates of the programme, RUFIN trained 27 MFBs (MDs/Credit Officers) on product development. This has resulted in improved financial products piloted by MFBs and increased deposit mobilization. Also, 33 MFBs have been trained on Risk Management while 1,524 staff of RMFls were trained on Gender Learning and Action System, Making Microfinance Work, Enterprise Management and Governance and entrepreneurial Skill Development. In order to enhance client outreach through establishing linkages between RMFls and formal Banks, 3,516 Rural Microfinance Institutions have been linked with formal banks. A total of N66,598,865.88 of voluntary savings have been mobilized from 31,149 savers in the 12 participating states. Out of these $44.68 \%$ of these savers were women, while $55.32 \%$ were men. A further analysis showed that $20.69 \%$ were youths while $0.91 \%$ are physically challenged. The total wholesale credit amounting to N134,756,484 was provided to the village savings and credit associations for onward lending to their members/ clients in the participating states. The programme has formed and strengthened 6,295 village credit and savings groups consisting of 149,990 members in the 12 participating states. In addition, 529 RMFls with 1413 members were trained on gender learning and action system, making microfinance work and governance etc in 11 states consisting of 875 men and 38 women.

Access to credit facilities has increased by $122.24 \%$ from N60,636,845.45 in June, 2011 to N134,756,484 in February, 2012. Savings mobilization, increased by 226.23\% from N20, 546,189.43 in December, 2010 to the current value of N67,562,505.88 in February, 2012. An Online Report Rendition Workshop conducted in collaboration with Other Financial Institutions Supervision Department (OFISD) of the Central Bank of Nigeria (CBN) for Micro Finance Banks in the country. In an effort to facilitate increased wholesale lending and refinance facility for the Microfinance Institutions, the Bank of Agriculture (BOA) dedicated N1 million for the refinancing of MFBs in 2011. In addition, the two Apex organisations - the National Association of Non-Bank Micro Finance Institutions and the National Association of Micro Finance Banks are being capacitated in the area of capacity building and ICT equipment to enable the two institutions carry out oversight functions on the entire Micro Finance Institutions in Nigeria.

\section{Conclusion}

In Nigeria, agriculture possesses substantial development potentials which has capacity to attract youth and women into the sector if properly harnessed. In this study we assessed past and current efforts towards encouraging youth and women in agriculture. We also looked at the constraints that youths and women are facing in agriculture as well as the available opportunities that should make them to want to stay in the venture. In addition, we examined the current population of Nigeria disaggregated by gender and age. We found that the youth and women constitute over $90 \%$ of the population and therefore must be engaged to feed the growing population. Many of the youth are still in their very active and productive age which placed them rightly to be empowered in order to pave way out of poverty and food insecurity that is a norm in many developing countries like Nigeria.

The constraints facing the youth and women are not just pushovers. Therefore, effort should be intensified and constructive approaches through polices that support pathways in which opportunities can be harnessed and constraints offed. For instance, inheritance laws and customs that make the transfer of land 
to young women prohibitive should be checked; Promotion of financial products that catered specifically for youth and women, mentoring programmes and start-up funding opportunities should be emphasized; harnessing and catalyzing the entrepreneurial spirit and skills of young farmers and women by providing technical and financial assistance, vocational and business management training, including guidance for joint endeavors, team spirit and cooperation. Beyond technical skills, building capacity for agribusiness, decision-making, communication and leadership should also be central along the agricultural value chain. Many youth and women are discouraged to go into agriculture due to the global warming that makes weather to be unpredictable thereby causing low harvest and reduced income. Government can encourage youth and women to go for agriculture by providing insurance for their entire farm produce in case of loss due to weather. Agricultural value chain analysis should be done and projected to youth to see the value in going into different sectors of agriculture apart from primary production. Food scientists should be tasked to discover new foods that can be derived from untapped agricultural products like maize, cocoa, cassava, cashew among others.

\section{How to Cite this Article:}

Abioye O. \& Ogunniyi A. (2018, January 1). Coldspots and Hotspots of Agriculture in Nigeria; Any Hope for Youth and Women? Advanced Journal of Social Science, 2(1), 1-11. doi: 10.21467/ajss.2.1.1-11

\section{References:}

Adesugba M. and Mavrotas G. (2016) Delving Deeper into the Agricultural Transformation and Youth Employment Nexus: The Nigerian Case. International Food Policy Research Institute, working paper 31.

Adeogun S. O. (2015). Participatory Diagnostic Survey Of Constraints To Youth Involvement In Cocoa Production In Cross River State Of Nigeria. Journal of Agricultural Sciences Vol. 60, No. 2, 2015, Pages 211-225.

AFDB (2016) Feed Africa-Strategy_for_Agricultural_Transformation_in_Africa_2016-2025.

AFDB (2016) AfDB Group provides USD 250 million to support ENABLE Youth Nigeria program. Accessed November $20,2017$. https://www.afdb.org/en/news-and-events/afdb-group-provides-usd-250-million-to-support-enable-youth-nigeria-program$\underline{16579 /}$

Akande T. (2014) Youth Unemployment in Nigeria: A Situation Analysis. Accessed November 20 , 2017. https://www.brookings.edu/blog/africa-in-focus/2014/09/23/youth-unemployment-in-nigeria-a-situation-analysis/

Akpan, S. B. (2010): Encouraging Youth's Involvement in Agricultural Production and Processing. In International Food Policy Research Institute Nigeria Strategy Support Program Policy Note No. 29.

Anyanwu J.C. and Uwatt U.B. (1993) Banking for the poor: the case of the People's Bank of Nigeria. African Review of Money Finance and Banking, No. 1, pp. 87-103

Bakare A.S. (2011) The Determinant of Urban Unemployment Crises in Nigeria: An Econometric Analysis. Journal of Emerging Trends in Economics and Management Sciences, 2 (3): 184-192

Federal Government of Nigeria Climate Change Adaptation and Agribusiness Support Programme in the Savannah Belt (CASP) Final Programme Report (2013).

Okoye C. U. and Okpala A.O (2001) The history of community banking and its role in Nigerian rural economic development. The Review of Black Poli $\square$ cal Economy. Vol. 28, No3

De Soto, H. (2000). The Mystery of Capital: Why Capitalism Triumphs in the West and Fails Everywhere Else. London: Bantam Press.

Dyer K. W. (2013). Young People and Agri-food: Aspirations, Opportunities and Challenges FAC CAADP Policy Brief 09 | March 2013.

FAO (2014) Youth and agriculture: Key challenges and concrete solutions. Accessed November 20, 2017 http://www.fao.org/3/a-i3947e.pdf

FAO (2017) Nigeria at a glance. Accessed November 20, 2017 http://www.fao.org/nigeria/fao-in-nigeria/nigeria-at-a-glance/en/

Financial Quest (2017). FG Reserves 5,000 Hectares of Farm Land For Youth and Women in Kwali, Abuja. Accessed November 20, 2017 https://financialquest.com.ng/fg-reserves-5000-hectares-of-farm-land-for-youth-and-women-in-kwali-abuja/

FMARD (2017) The Rural Finance Institution Building Programme (RUFIN). Accessed November 20, 2017 http://fmard.gov.ng/home/rufin/

Fair Labor Association (2015). Situational Assessment Of Women And Youth Farmers And Family Nutritional Status In Two Cocoa Producing Communities In Côte D’ivoire. Improving Workers' Lives Worldwide.

African Entrepreneurship Award (2017). Accessed November 20, 2017 https://africanentrepreneurshipaward.com/

Godfray, H., J. Charles, J. R. Beddignton, I. R. Crute, et al. (2010). Food Security: The Challenge of Feeding 9 Billion People. Science, 327:812-817

Jayaram, K., J. Riese, and S. Sanghvi. (2010). Agriculture: Abundant opportunities. McKinsey Quarterly, Summer 2010.

Kakwagh venatus V \& Ikwuba A (2010), 'Youth unemployment in Nigeria: Causes and related issues', Canadian social science vol. 6, no. 4, pp. 231-237

Michener M. (2014): Commercial Access to Inputs in Africa. CFS Side Event: Smallholders' Access to Inputs in Africa

MIJARC/IFAD/FAO. 2012. Summary of the findings of the project implemented by MIJARC in collaboration with FAO and IFAD: 'Facilitating access of rural youth to agricultural activities'. The Farmers' Forum Youth session, 18 February 2012.

National Planning Commission, NPC (2013): Mid-Term Report of the Transformation Agenda, May 2011 - May 2013: Taking Stock, Moving Forward. Abuja. 
Oyewale et al. Adv. J Social Sci.; Vol. 2 Issue 1, pp: 1-11, May 2018

Nwajiuba C (2013) Nigeria's Agriculture and Food Security Challenges, Accessed November 20, 2017. https://ng.boell.org/sites/default/files/uploads/2013/10/agriculture___green_deal_nigeria_study.pdf

Njenga P., Mugo F., Opiyo R. (2013) Youth and Women Empowerment through Agriculture in Kenya.

Laven A., and Verhart N., (2012) Women \& Cocoa Farming: "Bridging The Gap" Women in Cocoa Farming Presentations. Royal Tropical Issue.

UN DESA (2015), Accessed November 20, 2017 http://www.un.org/en/development/desa/news/population/2015-report.html

UNCTAD. (2010). Enhancing food security in Africa through science, technology, and innovation. Technology and Innovation Report 2010. United Nations Conference on Trade and Development.

Olokundun A.M., Falola B.H., Ibidunni A.S., (2014) Agro Business as a Remedy for Youth Unemployment towards the Achievement of Sustainable Development in Nigeria: Comparative Perspectives from the Kwara State Agro Business Economy. Journal of Economics and Sustainable Development. Vol.5, No.3.

Skuza, J.A. (2005): Site based youth development programmes: Reaching understanding youth targeted communities. Journal of Extension 42:20-26.

The Tony Elumelu Foundation - Supporting entrepreneurship in Africa, Accessed November 20, 2017 http://tonyelumelufoundation.org/

World Bank (2015). World Development Indicators. Washington DC: World Bank.

Youwin!, Accessed November 20, 2017 https://en.wikipedia.org/wiki/Youwin!\#The Phases of YouWin

Zero Hunger (2016) Synthesis Report of the Nigeria Zero Hunger Strategic Review. 60 pp

\section{Publish your research article in AIJR journals-}

$\checkmark$ Online Submission and Tracking

$\checkmark$ Peer Reviewed

$\checkmark$ Rapid decision

$\checkmark$ Immediate Publication after acceptance

$\checkmark$ Open Access (Articles freely available online)

$\checkmark$ Retain full copyright of your article.

Submit your article at journals.aijr.in 